\section{Not-from-concentrate Blueberry Juice Extraction Utilizing Frozen Fruit, Heated Mash, and Enzyme Processes}

\author{
Rebecca E. Stein-Chisholm ${ }^{1,3}$, John W. Finley ${ }^{1}$, Jack N. Losso ${ }^{1}$, \\ and John C. Beaulieu ${ }^{2,4}$
}

AdDitional INDEX wORDs. juice processing, Vaccinium ashei, Vaccinium corymbosum, press cake, juice recovery, small-scale production

SUMMARY. Juice production is a multibillion dollar industry and an economical way to use fruit past seasonal harvests. To evaluate how production steps influence notfrom-concentrate (NFC) blueberry (Vaccinium sp.) juice recovery, bench top and pilot scale experiments were performed. In bench-top, southern highbush (SHB) blueberry (Vaccinium darrowii $\times$ Vaccinium corymbosum) and rabbiteye blueberry (RAB) (Vaccinium ashei) were pressed at varying temperatures. Press treatments included ambient temperature, frozen then thawed, and frozen then heated berries. In addition, two commercial pectinase enzymes were evaluated. Three batches were pressed and average juice recovery was calculated. The highest average free juice recovery $(68.8 \% \pm 1.1 \%)$ was attained by heating frozen berries and treating with enzyme. Comparing berry species pressed, SHB blueberries produced significantly more juice than RABs. There were no significant differences between enzymes used between berry species. Using this preliminary data, the optimum juice recovery method was then transferred to pilot scale processing. RABs were heated and treated with enzyme then pressed. Free juice recovery from the pilot scale was $74.0 \% \pm 1.0 \%$. Total juice recovery was calculated to be $87 \% \pm 0.6 \%$. With this information, further refinement of juice processes could increase juice production output for small-scale producers and expand local outlets for growers to market their crops as well as create new opportunities for growth in the fresh juice market segment.

$\mathrm{D}$ ue to recent research involving health benefits of phytochemicals, development of the functional foods segment, and keen marketing, certain fruits have been portrayed as "superfruits" causing an increase in demand (Folmer et al.,

We would like to thank Donna Marshall-Shaw and Lavonne Stringer at the Thad Cochran Southern Horticultural Laboratory, USDA, ARS in Poplarville, MS for their help with the blueberries. We also express thanks to Pete Whitehead, Goodnature Products, Inc., for his advice regarding hydraulic pressing and the supplemental pressing data.

This article is a U.S. government work and is in the public domain in the United States. Mention of a trademark or proprietary product is for identification only and does not imply a guarantee or warranty of the product by the U.S. Department of Agriculture. The U.S. Department of Agriculture prohibits discrimination in all its programs and activities on the basis of race, color, national origin, gender, religion, age, disability, political beliefs, sexual orientation, and marital or family status.

${ }^{1}$ Louisiana State University, School of Nutrition and Food Sciences, 297 Knapp Hall, Baton Rouge, LA, 70803

${ }^{2}$ U.S. Department of Agriculture, Agricultural Research Service, 1100 Robert E. Lee Boulevard, New Orleans, LA 70124

${ }^{3}$ The Lubrizol Corporation, 1097 Yates Street, Lewisville, TX 75057

${ }^{4}$ Corresponding author. E-mail: john.beaulieu@ars. usda.gov.

doi: 10.21273/HORTTECH03449-16
2014; Khurana et al., 2013). Blueberries have seen much of this popularity in recent years and have been incorporated into various food products including baked goods, beverages, and snacks for every market segment. Increased blueberry demand has resulted in increased productions and crop value over the last decade. Production in the United States in 2014 was 563.2 million pounds with a value of $\$ 824.9$ million (U.S. Department of Agriculture, 2015). In the southeastern U.S. (Alabama, Arkansas, Florida, Georgia, Mississippi, and North Carolina) blueberry production more than tripled and value increased 4-fold from 2002 to
2012 [37.6 to 128.2 million pounds and $\$ 194.6$ million to $\$ 781.8$ million, respectively (U.S. Department of Agriculture, 2013a, 2013b)].

In addition to fresh berry consumption, blueberry juice has increased as a popular ingredient in mixed fruit beverages as well as $100 \%$ single strength fruit juice options (SunWaterhouse, 2011). Availability of fresh-squeezed juices in restaurants, supermarkets, and coffee shops are increasing consumer demands for more local juice options (Watrous, 2014). Public awareness of the benefits of blueberries and the development of functional food products is opening opportunities for alternative markets and small-scale producers to get involved in the market with residual high-quality fruit not sold as fresh.

Processing fruit into juice is a popular product option and a way to extend marketing windows and shelf life of the berries (Perera and Smith, 2013). Recent research studies indicate that blueberries provide unequivocal health benefits which translate directly to increased production and consumption, positioning blueberries as a great fruit option for use in NFC juices. NFC juices oftentimes offer an economically attractive alternative to fresh sales with an $8 \%$ average annual growth through 2014 (Barkla, 2011). NFC juice products are gaining in popularity as an alternative niche market compared with concentrated and reconstituted juices. Producing juice from fresh local berries is limited to 3 months out of the year for producers due to the blueberry harvesting season (Puls, 1999). Concentrating juice can be an expensive step and removing this from the process can save time and money for smallscale producers. This makes NFC processes less costly and more attractive to small-scale producers (Bates et al., 2001), especially if frozen berries may

\begin{tabular}{llll}
\hline $\begin{array}{l}\text { Units } \\
\begin{array}{l}\text { To convert U.S. to SI, } \\
\text { multiply by }\end{array}\end{array}$ & U.S. unit & SI unit & $\begin{array}{l}\text { To convert SI to U.S., } \\
\text { multiply by }\end{array}$ \\
\hline 10 & $\%$ & $\mathrm{mg} \cdot \mathrm{g}^{-1}$ & 0.1 \\
29.5735 & $\mathrm{fl} \mathrm{oz}$ & $\mathrm{mL}$ & 0.0338 \\
3.7854 & $\mathrm{gal}$ & $\mathrm{L}$ & 0.2642 \\
0.4536 & $\mathrm{lb}$ & $\mathrm{kg}$ & 2.2046 \\
28.3495 & $\mathrm{oz}$ & $\mathrm{g}$ & 0.0353 \\
0.001 & $\mathrm{ppm}$ & $\mathrm{mg} \cdot \mathrm{mL}^{-1}$ & 1,000 \\
1 & $\mathrm{ppm}$ & $\mathrm{mg} \cdot \mathrm{kg}^{-1}$ & 1 \\
0.0069 & $\mathrm{psi}$ & $\mathrm{MPa}$ & 145.0377 \\
0.9464 & $\mathrm{qt}$ & $\mathrm{L}$ & 1.0567 \\
$\left({ }^{\circ} \mathrm{F}-32\right) \div 1.8$ & ${ }^{\circ} \mathrm{F}$ & ${ }^{\circ} \mathrm{C}$ & $\left({ }^{\circ} \mathrm{C} \times 1.8\right)+32$
\end{tabular}


be used. Information on use of RABs and SHB blueberries in NFC processing, including use of frozen and fresh berries, if available, would benefit small-scale producer's decision-making processes and juice recoveries.

The process of producing juice varies and may include freezing, heating, and enzyme treatments (Howard et al., 2012). Berries can be frozen after harvesting to reduce the effects of pectin and gelling, as well as to extend utilization beyond the narrow harvest season (Gössinger et al., 2009). To improve juice recovery, berries can be treated with elevated temperatures. Heating or blanching the berries before pressing is a common step used in juicing fruits (Brownmiller et al., 2008). Pressing heated berries extracts more juice and color pigments while cold pressing results in lower yield, less bodied, lighter character juices (Gerard and Roberts, 2004; Lee et al., 2002). In addition to increased juice recovery, the elevated temperature also denatures native enzymes, such as polyphenol oxidase, that can otherwise cause degradation of flavor, color, and phytochemical levels (Patras et al., 2010). Enzymes derived from bacteria, such as Aspergillus niger and Aspergillus aculeatus, can be used to improve extraction from plant tissues and liquefaction, increase juice yield, clarification, and filtration (Landbo et al., 2007). Pectinase enzymes increase juice yield by breaking down the pectin in the cell walls and in the middle lamellae between the cells (Grassin and Fauquembergue, 1996). Enzymes, along with the heat, can contribute to the breakdown of associated pectin, phenolic, and lipid components that are known to create bitter/astringent flavors and lead to precipitation and color instability during storage (Horváth-Kerkai, 2007). It is important to evaluate the optimum extraction temperature, time, and enzymatic treatments to maximize the juice recovery as well as desired color and flavor attributes (Howard et al., 2012). The importance of juice recovery is essential for smallscale producers to maximize their product output and profits.

Subsequently, these experiments evaluated two species of local blueberries commonly grown in the southern United States to establish a general baseline for small-scale juice recovery of $\mathrm{SHB}$ and $\mathrm{RAB}$ blueberries treated with heat and enzymes before pressing. By evaluating how mash temperature and enzymatic processing can affect the amount of juice recovered, combinations of temperatures and enzyme processing steps were applied to determine their influence on juice recovery. The best combination of temperature and enzyme treatments was then conveyed in a scaled up pilot plant experiment using heat and enzymes.

\section{Materials and methods}

Preliminary press weight. To optimize the efficiency of the press, an initial berry weight experiment was performed with a 2.2 -L bench top stainless steel screw fruit press (model 11065; Ferrari Group, Parma, Italy) fitted with a custom-cut nylon mesh fabric pressing sack (no. 2623; Goodnature Products, Orchard Park, NY) (Supplemental Fig. 1). 'Tifblue' RAB blueberries were harvested from the Louisiana State University Bob R. Jones-Idlewild Research Station in Clinton, LA, in June 2011 and stored at $-20{ }^{\circ} \mathrm{C}$ until sampled. Thawed RAB blueberry samples of 500,750 , and $1000 \mathrm{~g}$ were tested for juicing ease in the bench top press. For preliminary presses, three presses were repeated at each weight and the juice, press cloth, and press cake weights were recorded. The juice and press cake recovery averages were calculated and the highest average yielding weight (1000 g) was chosen as the optimal sample size to be used for the bench top experiment.

BENCH TOP PRESS. Blueberry varieties were chosen using data $\mathrm{col}^{-}$ lected from a prior evaluation of several local varieties harvested from multiple locations. This evaluation consisted of hand-pressing fresh and thawed berries in cheesecloth to assess degree of enzymatic browning and pectin-associated gelling. Two varieties of SHB blueberries (Magnolia and Biloxi) and two varieties of RAB blueberries (Columbus and Montgomery) were selected from this evaluation. These four varieties did not exhibit excessive browning or gelling, as confirmed by a local expert (D.A. Marshall, personal communication), and were harvested from the Thad Cochran Southern Horticultural Laboratory plots in Poplarville, MS, in June 2011 and 2012. After harvesting, all berries were transported on ice, washed, dried at $4{ }^{\circ} \mathrm{C}$, frozen in large plastic freezer bags, and stored at $-20{ }^{\circ} \mathrm{C}$ until sampling.
Two varieties from each year were mixed together in equal quantities to create the berry type ( $\mathrm{SHB}$ or $\mathrm{RAB}$ ) frozen samples. This was accomplished because generally, secondary fruit (not primary fresh market fruit) ends up mixed and aggregated for other food uses (freezing, canning, juicing, etc.). A small amount of fresh 2012 berries were stored at $4^{\circ} \mathrm{C}$ for $2 \mathrm{~d}$ before use as "fresh ambient" temperature samples.

Process treatments. Based on initial presses made to evaluate press function, it was determined that pressing fresh berries with no other processing did not render adequate juice due to lack of liquefaction. Therefore, only one berry type (SHB blueberry) was chosen to make a fresh vs. frozen comparison. Fresh 2012 SHB blueberries were pressed at ambient temperatures $\left(25^{\circ} \mathrm{C}\right)$ for the fresh control, whereas another set of fresh $2012 \mathrm{SHB}$ blueberries were heated for about $15 \mathrm{~min}$ to a temperature of $95^{\circ} \mathrm{C}$ for $3 \mathrm{~min}$ and pressed hot for the heated control. Thereafter, frozen berries for both berry species were treated as follows. Berries to be pressed at ambient temperature were removed from the freezer and allowed to warm for $30 \mathrm{~min}$ in a beaker placed in an ambient temperature water bath $\left(25^{\circ} \mathrm{C}\right)$. Berries that received heat treatments were placed, still frozen, in a beaker and heated on a hot plate for $15 \mathrm{~min}$ to $95^{\circ} \mathrm{C}$ and held for 3 min maintaining temperature with constant stirring (Supplemental Fig. 2) and pressed hot. Each press was opened and the press cake was manually broken up, redistributed and repressed. Mash to be treated with enzyme, was cooled to $50{ }^{\circ} \mathrm{C}$ and two different commercial enzymes routinely used for berry operations were used, at concentrations suggested $\left(200 \mathrm{mg} \cdot \mathrm{kg}^{-1}\right)$ for berry mash. Rohapect 10 L (AB Enzymes, Darmstadt, Germany) is a pectinase that is recommended for low $\mathrm{pH}$ juices (Moss, 1992). Aside from the source (A. niger), the specific type of pectinase was not labeled by the manufacturer. Pectinex BE XXL (Novozymes, Bagsvaerd, Denmark) is a pectin lyase which catalyzes the random cleavage of the pectin molecule, especially in highly esterified pectin chains, in acidic fruits (Moss, 1992). Mash treated with enzyme was stirred on a stir plate for $1 \mathrm{~h}$ before hot pressing at $45^{\circ} \mathrm{C}$. All process treatments were repeated three times. Free juice, press cakes, and nylon press bags were weighed and recoveries of 
free juice, press cake, juice loss, and total juice were calculated and averaged. The highest free juice recovery treatment process was then transferred to the pilot scale press experiment.

RAPID QUALITATIVE APPRAISALS. Physical measurements of total soluble solids (TSS), $\mathrm{pH}$, and titratable acidity (TA) were measured from each repetition. TSS were measured with a digital, handheld refractometer (Pocket PAL-1: Atago, Tokyo, Japan). Measurements for $\mathrm{pH}$ and $\mathrm{TA}$ were measured with $10 \mathrm{~mL}$ juice on an automated titration unit (836 Titrando: Metrohm, Herisau, Switzerland) with a titration endpoint $\mathrm{pH} 8.2$, using $0.1 \mathrm{~N}$ sodium hydroxide. Titratable acidity was calculated as percent citric acid (wt/wt).

Pilot scale press. Pilot scale processing used 'Tifblue' RAB blueberries harvested in June 2012 by Blue River Farms, LLC (Mt. Olive, MS) that were blast frozen (forced air -23 to $-29^{\circ} \mathrm{C}$ for $72 \mathrm{~h}$ ) and stored at $-20^{\circ} \mathrm{C}$ until sampled. 'Tifblue' RAB blueberries were used for the pilot scale press since a large supply could be harvested, and 'Tifblue' is considered the standard variety to which $\mathrm{RAB}$ blueberries are compared (Marshall et al., 2006). Each 60-lb batch of frozen berries was heated for close to $15 \mathrm{~min}$ to reach $95{ }^{\circ} \mathrm{C}$ in a 40 -qt stainless steel steam jacketed kettle (Groen, Jackson, MS) with constant stirring, and held for 3 min (Supplemental Fig. 3). Mash was poured into stainless steel vessels and cooled to $50{ }^{\circ} \mathrm{C}$ and enzyme treated with $200 \mathrm{mg} \cdot \mathrm{kg}^{-1}$ of Rohapect $10 \mathrm{~L}$ for $\mathrm{l} \mathrm{h}$ then pressed warm $\left(45^{\circ} \mathrm{C}\right)$ in an single-layer hydraulic press (model X-1; Goodnature Products) at 1800 psi using a medium-weave polyester mesh press bag (mesh size no. 2636) for 1 min (Supplemental Fig. 4). The entire juice process was repeated three times. Free juice, press cakes, and press bags were weighed and recoveries of free juice, press cake, juice loss, and total juice were calculated and averaged. Free juice was considered the free flowing juice that was collected. Press cake was the pulp, skins, and seeds that remained in the nylon fabric press bag (Supplemental Fig. 5). Juice loss was the amount of juice lost in the mashing and pressing stages, including transfers and losses within the nylon press bags. The total juice recovery was the free juice plus the juice loss.

STATISTICAL ANALYSIs. Results are presented as mean $\pm \mathrm{SD}$. Values obtained by experimentation are presented as the mean of three repetitions. Statistical analysis was carried out using SAS (version 9.4; SAS Institute, Cary, NC) using analysis of variance. The means and standard deviations were compared using Tukey's Studentized range test with $P \leq 0.05$.

\section{Results and discussion}

Preliminary press weight. The preliminary juicing sample size experiment indicated that regardless of the amount of berries pressed, the Ferrari press extracted the same percentage of free juice from the berries with no statistical difference. The average free juice weight from the $500-\mathrm{g}$ press weight was $365.7 \pm 9.6 \mathrm{~g}$ with a $73.1 \% \pm 1.9 \%$ free juice recovery. For the $750-\mathrm{g}$ press weight, $545.7 \pm$ $12.3 \mathrm{~g}$ with a $72.7 \% \pm 1.7 \%$ free juice recovery was produced. The $1000-\mathrm{g}$ press weight produced $744.3 \pm 4.0 \mathrm{~g}$ of free juice on average with $74.4 \% \pm$ $0.4 \%$ recovery for free juice. Looking to factors in addition to free juice, the $1000-\mathrm{g}$ presses produced uniform press cakes with lower visible moisture content than the smaller weight presses which resembled pilot scale presses. Using this preliminary data, the 1000 -g weight was chosen to be used for the remaining heat and enzyme press experiments.

FreE JUICE RECOVERY FROM BENCH TOP PRESSES. Fresh SHB blueberries were pressed at either ambient temperature $\left(25^{\circ} \mathrm{C}\right)$ or at $45^{\circ} \mathrm{C}$ after heating to $95{ }^{\circ} \mathrm{C}$ as controls to see the influence of pressing temperature on free juice recovery. The SHB blueberry fresh ambient temperature presses resulted in the lowest average free juice recovery with $42.1 \% \pm 4.6 \%$. Fresh $\mathrm{SHB}$ blueberries that were heated to $95{ }^{\circ} \mathrm{C}$ produced the most juice of the entire experiment, with $71.1 \% \pm 1.8 \%$ average free juice recovery. The SHB blueberry fresh heated presses were significantly greater than the SHB blueberry fresh ambient temperature presses. Thawed SHB blueberries pressed at ambient temperature produced $61.4 \% \pm 7.4 \%$ average free juice recoveries; a $19.3 \%$ improvement over the SHB blueberry fresh ambient temperature presses. There was no significant difference between the SHB blueberry fresh heated and the SHB blueberry frozen heated presses, without enzyme treatment. The effect of freezing was minimal, with average free juice recoveries of $71.1 \% \pm 1.8 \%$ for the fresh SHB blueberry heated presses and $68.6 \% \pm$ $2.6 \%$ for frozen SHB blueberry heated presses. This demonstrates short term freezing of berries before processing does not significantly change free juice recovery. However, the process in which berries are frozen is important to maintain the quality and quantity of the juice (Reque et al., 2014). Results from the RAB blueberry presses were similar to the frozen SHB blueberry presses (Table 1). Thawed RAB blueberry ambient temperature presses had the next significantly lowest recovery of the experiment with $45.9 \% \pm 6.0 \%$ average free juice recovery. Heating the frozen $\mathrm{RAB}$ blueberries before pressing improved the average free juice recovery by almost $15 \%$ over the thawed RAB blueberry ambient temperature presses (Table 1). Pressing thawed berries confirmed that pectin was not degraded by freezing temperatures alone and could affect juice recovery if not properly addressed. Heating berries before pressing degrades pectin molecules to varying degrees depending on the degrees of methylation, $\mathrm{pH}$ range, and temperature (Diaz et al., 2007). However, this heat step does not completely prevent pectin from forming gel matrixes, since demethylation of some pectin chains can still create uninhibited chains and form strong matrixes (Diaz et al., 2007). Gelling during pressing can cause decreased free juice recovery and could have been a contributing factor in the lower recoveries observed in the ambient temperature presses (Table 1 ).

Comparing Rohapect $10 \mathrm{~L}$ and Pectinex BE XXL enzymes to each other within the same berry species, there was no significant difference in free juice recovery (Table 1 ). However a significant difference in recoveries between berry species was observed. SHB blueberry enzyme treated presses produced $9.0 \% \pm 4.6 \%$ more free juice than RAB blueberry presses. This could be because RAB blueberries contain more complex polysaccharides than SHB blueberries, which limit the enzyme activity (Deng et al., 2013). Regardless of berry species (SHB vs. RAB) or prepressing storage temperature (fresh vs. frozen), ambient temperature pressed berries had the lowest average percent juice recoveries $(49.8 \%)$ of the experiment. The heat and enzymetreated free juice recovery results from 
Table 1. Percent juice recovery in heat and enzyme treated Mississippi-grown southern highbush blueberry (SHB) and rabbiteye blueberry $(\mathrm{RAB})$ presses.

\begin{tabular}{|c|c|c|c|c|}
\hline \multirow[b]{2}{*}{ Juice process ${ }^{\mathrm{z}}$} & Free juice recovery & Press cake recovery & Total juice loss & Total juice recovery \\
\hline & \multicolumn{4}{|c|}{$[$ mean \pm SD (\%)] } \\
\hline $\mathrm{SHB}$, frozen, ambient temperature & $61.4 \pm 7.4 b^{y}$ & $31.3 \pm 4.1 \mathrm{~b}$ & $7.3 \pm 4.9 \mathrm{f}$ & $68.7 \pm 4.1 \mathrm{e}$ \\
\hline $\mathrm{SHB}$, frozen, $95^{\circ} \mathrm{C}, 10 \mathrm{~L}^{\mathrm{x}}$ & $68.6 \pm 1.1 \mathrm{ab}$ & $10.6 \pm 0.7 \mathrm{f}$ & $20.8 \pm 1.2 \mathrm{a}$ & $89.4 \pm 0.7 \mathrm{a}$ \\
\hline $\mathrm{SHB}$, frozen, $95^{\circ} \mathrm{C}, \mathrm{BE} \mathrm{XXL}{ }^{\mathrm{x}}$ & $67.3 \pm 3.8 \mathrm{ab}$ & $11.3 \pm 2.1 \mathrm{ef}$ & $21.4 \pm 2.2 \mathrm{a}$ & $88.7 \pm 2.1 \mathrm{ab}$ \\
\hline $\mathrm{RAB}$, frozen, ambient temperature & $45.9 \pm 6.0 \mathrm{~d}$ & $43.2 \pm 4.4 \mathrm{a}$ & $10.9 \pm 1.6 \mathrm{ef}$ & $56.8 \pm 4.4 \mathrm{f}$ \\
\hline $\mathrm{RAB}$, frozen, $95^{\circ} \mathrm{C}, \mathrm{BE}$ XXL & $62.5 \pm 4.2 \mathrm{bc}$ & $19.7 \pm 0.2 \mathrm{~cd}$ & $17.8 \pm 4.0 \mathrm{abc}$ & $80.3 \pm 0.2 \mathrm{~cd}$ \\
\hline Pilot, $\mathrm{RAB}$, frozen, $95^{\circ} \mathrm{C}, 10 \mathrm{~L}^{\mathrm{w}}$ & $74.0 \pm 1.0$ & $13.0 \pm 0.6$ & $13.0 \pm 0.5$ & $87.0 \pm 0.6$ \\
\hline
\end{tabular}

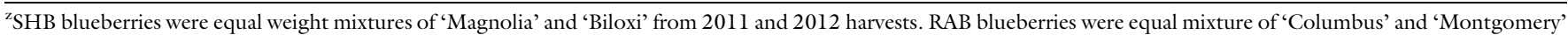
from 2011 to 2012 harvests. RAB pilot press blueberries were 'Tifblue' from 2012.

${ }^{y}$ Any two means within a column not followed by the same letter are significantly different at $P \leq 0.05$ with Tukey's method.

${ }^{x}$ Commercial pectinase enzyme treatments: $10 \mathrm{~L}=$ Rohapect $10 \mathrm{~L}$ (AB Enzymes, Darmstadt, Germany) and BE XXL = Pectinex BE XXL (Novozyme, Bagsvaerd, Denmark).

wilot plant experimental means are not compared against other bench top treatments.

this experiment are similar to the recoveries of Lee and others (2002), where northern highbush blueberry [NHB (V. corymbosum)] juice recovery was $75 \%$ to $83 \%$ using similar procedures. Overall, SHB blueberry presses produced higher free juice recoveries than RAB blueberry presses. This could also be due to the difference in the genetic background of the two berry types. Differences may include varying pectin content, native enzymes, sugar and water content, skin thickness, as well as the effect pectinase enzymes have on the intercellular structures of the berries (Boches et al., 2006; Gerard and Roberts, 2004; Pedrolli et al., 2009; Silva et al., 2005).

Juice recovery from fruits and vegetables depends greatly on the mass energy transfer of the press and several factors may affect this transfer including: the press design and operation, the ripeness of the fruit, the degree of milling, the mash treatments, and the number of outlets for drainage of juice during pressing (Jaeger et al., 2012). It is well documented that pretreating fruit with heat and enzymes increases juice yield (Jaeger et al., 2012). Juice recovery in other fruits, such as elderberry (Sambucus nigra) and blackcurrant (Ribes nigrum), using similar enzymes, showed consistent results with juice recoveries ranging from $75.0 \%$ to $77.5 \%$ (Landbo et al., 2007; Mieszczakowska-Fracc et al., 2012). Skrede et al. (2000) performed a study on NHB blueberry juice that attained an $83 \%$ juice yield after milling and heating the berries before pressing in a Wilmes bag press (Type 60; Moffet Co., San Jose, $\mathrm{CA})$. On the other hand, a study on
NHB blueberries blanched before pressing and treated with a depectinizing enzyme, yielded juice recoveries of $68 \%$ to $72 \%$ in a filter bag press (Brambilla et al., 2008). Variety and pressing protocols are important to maximize juice recovery whilst minimizing transfer and pressing losses which will increase profitability for the producer.

PRESS CAKE FROM BENCH TOP PRESSES. While juice recovery is the main product of processing, press cake is a by-product of the juicing process. It contains the skins and seeds left in the press after removing the juice. Initially, press cake has been regarded as a waste product, but new studies are exploring press cake uses and proving that press cake may be just as valuable as the juice (Thomasset et al., 2009). Theoretically, samples with the highest juice recoveries should have the lowest press cake amounts. Fresh SHB blueberries pressed at ambient temperatures produced the greatest average press cake amounts of $49.7 \% \pm$ $5.2 \%$. These presses resulted in low juice recovery and produced a viscous juice. Juices with high viscosity cause decreases in free juice recovery because the thick juice sticks to the press cake, as well as equipment and press cloth. To a producer, this reflects money lost if they do not further process the press cake in-house. Frozen SHB blueberry presses produced $25 \%$ less press cake than the fresh presses when pressed at ambient temperatures, but also produced $43 \%$ more press cake than the heated presses (Table 1). Heated fresh SHB blueberry presses resulted in $13.3 \% \pm 0.7 \%$ press cake. Thawed SHB blueberry ambient temperature presses resulted in $49 \%$ more press cake than heated SHB blueberry frozen presses. This may be attributed to the pectin gelling the juice since there was no heating. Heated SHB blueberry presses had $31 \%$ more press cake than the enzyme treated presses. SHB blueberry enzyme treated presses had significantly less juice lost in the press cake than SHB blueberry presses heated without enzyme. Percentage of press cake in all RAB blueberry presses paralleled results of the free juice recovery, with significant differences between the thawed RAB blueberry ambient temperature and frozen heated presses, as well as Rohapect $10 \mathrm{~L}$ enzyme and Pectinex BE XXL enzyme (Table 1). As with the free juice recovery, there were no significant differences between the frozen heated RAB blueberry presses and the enzyme press cake recoveries. Thawed RAB blueberry ambient temperature presses produced $44 \%$ more press cake than frozen heated presses and 55\% more than the enzyme treated press. All SHB blueberry presses had less press cake than all RAB blueberry presses (Table $1)$, which is congruent with the free juice recovery percentages and polysaccharide differences found between these berry species (Deng et al., 2013). There were also significant differences in press cake weights between the berry species and the two enzymes. This was likely caused by the way the enzymes affect the different types of pectins in the two berry species. The Rohapect $10 \mathrm{~L}$ is a pectinase, but not specifically labeled by the manufacturer. Pectinase includes many enzymes that break down pectic molecules and are mainly 
Table 2. Physical properties of free juice recovery in heat and enzyme treated Mississippi-grown southern highbush blueberry $(\mathrm{SHB})$ and rabbiteye blueberry $(\mathrm{RAB})$ presses.

\begin{tabular}{|c|c|c|c|}
\hline Juice process $^{z}$ & $\begin{array}{l}\text { Total soluble solids } \\
{[\text { mean } \pm \text { SD }(\%)]}\end{array}$ & $\mathrm{pH}($ mean $\pm \mathrm{SD})$ & 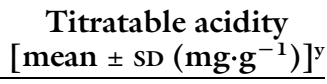 \\
\hline SHB, fresh, ambient & $12.4 \pm 0.46 \mathrm{~cd}^{\mathrm{x}}$ & $3.2 \pm 0.02 \mathrm{~b}$ & $0.45 \pm 0.08 \mathrm{~cd}$ \\
\hline $\mathrm{SHB}$, fresh, $95^{\circ} \mathrm{C}\left(203.0^{\circ} \mathrm{F}\right)$ & $15.1 \pm 0.32 \mathrm{abc}$ & $3.4 \pm 0.03 \mathrm{ab}$ & $0.55 \pm 0.07 \mathrm{abcd}$ \\
\hline $\mathrm{SHB}$, frozen, ambient temperature & $13.8 \pm 0.46 \mathrm{bcd}$ & $3.4 \pm 0.05 \mathrm{ab}$ & $0.46 \pm 0.04 \mathrm{bcd}$ \\
\hline $\mathrm{SHB}$, frozen, $95^{\circ} \mathrm{C}$ & $16.3 \pm 3.16 \mathrm{ab}$ & $3.4 \pm 0.04 \mathrm{ab}$ & $0.46 \pm 0.05 \mathrm{bcd}$ \\
\hline $\mathrm{SHB}$, frozen, $95^{\circ} \mathrm{C}, 10 \mathrm{~L}^{\mathrm{w}}$ & $16.9 \pm 0.68 \mathrm{ab}$ & $3.3 \pm 0.09 \mathrm{ab}$ & $0.61 \pm 0.02 \mathrm{abc}$ \\
\hline $\mathrm{RAB}$, frozen, $95^{\circ} \mathrm{C}$ & $13.0 \pm 1.13 \mathrm{bcd}$ & $3.3 \pm 0.04 \mathrm{~cd}$ & $0.62 \pm 0.06 \mathrm{ab}$ \\
\hline $\mathrm{RAB}$, frozen, $95^{\circ} \mathrm{C}, 10 \mathrm{~L}$ & $15.2 \pm 0.72 \mathrm{abc}$ & $3.2 \pm 0.03 \mathrm{~b}$ & $0.61 \pm 0.08 \mathrm{ab}$ \\
\hline $\mathrm{RAB}$, frozen, $95^{\circ} \mathrm{C}, \mathrm{BE} \mathrm{XXL}$ & $15.6 \pm 0.74 \mathrm{abc}$ & $3.1 \pm 0.03 \mathrm{~b}$ & $0.66 \pm 0.07 \mathrm{a}$ \\
\hline Pilot, $\mathrm{RAB}$, frozen, $95^{\circ} \mathrm{C}, 10 \mathrm{~L}^{\mathrm{v}}$ & $14.2 \pm 0.2$ & $3.2 \pm 0.04$ & $0.40 \pm 0.04$ \\
\hline
\end{tabular}

${ }^{\mathrm{z}}$ Only fresh SHB berries were pressed fresh due to knowledge of difficulties with gelling of the juice due to pectin content detailed in the literature and in our preliminary experiments. SHB blueberries were equal weight mixtures of 'Magnolia' and 'Biloxi' from 2011 and 2012 harvests. RAB blueberries were equal mixture of 'Columbus' and 'Montgomery' from 2011 and 2012 harvests. RAB pilot press blueberries were 'Tifblue' from 2012.

${ }^{y} 1 \mathrm{mg} \cdot \mathrm{g}^{-1}=0.1 \%$.

${ }^{x}$ Any two means within a column not followed by the same letter are significantly different at $P \leq 0.05$ with Tukey's method.

${ }^{w}$ Commercial pectinase enzyme treatments: $10 \mathrm{~L}=$ Rohapect $10 \mathrm{~L}$ (AB Enzymes, Darmstadt, Germany) and BE XXL = Pectinex BE XXL (Novozyme, Bagsvaerd, Denmark). 'Pilot plant experimental means are not compared against other bench top treatments.

produced from plant pathogenic microbes (Pedrolli et al., 2009). Many commercial pectinase mixes are not pure sources of enzyme, but may include other enzymes including proteases (Pedrolli et al., 2009). The Novozyme Pectinex BE XXL is a pectin lyase and is recommended for acidic fruits, catalyzing the random cleavage of the pectin molecule, especially in highly esterified pectin chains (Pedrolli et al., 2009). The pectins in the RAB blueberries are more complex than the SHB blueberries (Deng et al., 2013). Pectins are affected by temperature, the degree of esterification and acetylation, $\mathrm{pH}$, sugar types and quantities, and other solutes (Pedrolli et al., 2009). Subsequently, based on enzyme function, the two enzymes used will degrade pectin in different ways. The pectins in the SHB blueberries were apparently more easily degraded by the enzymes, allowing smaller, less active fragments of pectin to be removed from the press cake with the juice during pressing (Table 1 ). In the RAB blueberries, the enzymes were likely limited by the branches of the pectin molecules, creating similar amounts of juice as the SHB blueberries, but keeping more pectin and subsequently weight in the press cake.

JUICE AND PRESS CAKE RECOVERY IN PILOT PRESSES. Using the data from the bench top experiment, it was determined that both enzymes produced statistically similar results. Therefore, Rohapect $10 \mathrm{~L}$ enzyme was randomly chosen to scale up to the pilot plant on frozen heated berries. The average free juice recovery for the pilot presses was $74.0 \% \pm 1.0 \%$ and had $13.0 \% \pm 0.6 \%$ of press cake (Table 1 ).

\section{Juice loss and total juice recovery for bench top and pilot presses}

JUICE LOss. Residual juice remaining in containers after progressing through juicing steps (including additional transfers and weighing steps), as well as juice trapped in the woven strands of the press cake and cloth, all contribute to juice loss and total juice recovery. Using data from single presses in clean holding vessels and dry press cloths, press cloth juice was calculated and added to the juice loss for total juice recovery. Since juice producers would make several presses before changing out the cloth, and presumably reuse holding vessels repeatedly, we have overestimated the "loss." Commercially, the major juice loss would come from stopping the production to clean and sanitize the equipment. Juice loss varied throughout all the treatments (Table 1). Ambient temperature presses produced significantly higher amounts of press cake (e.g., 49.7\%), but resulted in lower juice loss since the berries did not press well. Fresh SHB blueberry ambient temperature presses resulted in only $8.3 \% \pm 2.3 \%$ total juice loss since much of the pressed juice not recovered in the free juice was accounted for in the press cake. Heated fresh SHB blueberry presses had higher amounts of juice loss with $15.5 \% \pm 1.2 \%$. Frozen heated presses without enzyme from both berry species produced similar losses of $15 \%$. Juice loss from nonenzymatically treated juices was attributed to the increased juice viscosity. Enzyme presses resulted in significantly more juice loss than the ambient temperature presses (Table 1). The enzyme treated juices have the greatest relative loss due to a small amount of water evaporation from the mash during the heating step and spillage from less viscous mashes in the pressing step. The average $13.0 \% \pm 0.5 \%$ loss from the pilot press was lower compared with the smaller bench top presses. To compare loss as a relative percentage of free juice, the total juice loss was divided by the free juice and a percentage was calculated. Calculating as such, bench top RAB blueberry 10 L enzyme treatment processes resulted in $31.8 \%$ loss whereas the pilot RAB blueberry $10 \mathrm{~L}$ enzyme treatments had only $17.6 \%$ loss due to more efficient press equipment.

Total Juice Recovery. Total juice recovery was calculated by adding the total juice loss to the free juice. Fresh SHB blueberry ambient temperature presses still had the lowest total juice recovery with $50.3 \% \pm$ $5.2 \%$, whereas fresh heated SHB blueberry presses produced $86.7 \% \pm 0.7 \%$. Fresh heated SHB blueberry total juice recovery was not drastically different from the enzyme treated presses for both berry species, including the pilot presses. The ambient temperature 
presses had 30\% less total juice recovery than the heated presses. For both berry species, the fresh heated ( $\mathrm{SHB}$ blueberry only) and frozen heated average total juice recoveries were significantly greater than the ambient temperature pressed berries. There was an average of $22 \%$ more total juice recovered from enzyme treatments compared with those heated treatments without enzymes. The resulting average pilot free juice recovery of $87.0 \% \pm 0.6 \%$ was comparable to other juice recovery experiments in the literature (Brambilla et al., 2008; Lee et al., 2002; Skrede et al., 2000). Comparing the pilot presses to the bench top RAB blueberry Rohopect $10 \mathrm{~L}$ enzyme presses, the pilot press delivered an average of $18 \%$ more juice from the berries and had $34 \%$ less press cake. We attribute dramatically less press cake weight recovery to the fact that a commercial-like enzymatic mashing and hydraulic press were implemented (per below).

Physical measurements of FREE JUICE. Differences in TSS between berry species were not significant (Table 2). Comparing the differences between the enzyme and temperature press, data indicates that both enzymes resulted in $22 \%$ more soluble solids than the ambient temperature pressed juices. This is due to the ability of the enzymes to break down the cell walls, liberating more lower molecular weight solutes and thus better liquefying the mash (Landbo et al., 2007). This same pattern was seen in the RAB blueberries with frozen ambient temperature presses compared with the heated enzyme presses. Heated enzyme presses had $24 \%$ more soluble solids (Table 2). The enzyme presses had significantly lower $\mathrm{pH}$ and higher TA compared with ambient temperature treatments. These results can relate back to the breakdown of cell walls and releasing cell contents. Resulting free juices produced from the pilot presses had soluble solids contents similar to the other free juices ( $14.2 \% \pm$ $0.2 \%$ TSS ). Amounts for TA and $\mathrm{pH}$ averages were $0.40 \pm 0.04$ and $3.2 \pm$ $0.04 \mathrm{mg} \cdot \mathrm{mL}^{-1}$, respectively (Table 2 ).

SUPPLEMENTARY PILOT PLANT PRESS DATA. Manufacturer's hydraulic press results delivered to owners or potential owners of the Goodnature X-1 press, show four press processes using thawed berries (Supplemental Table 1). The first press was cultivated blueberries without enzyme, but added $2 \%$ rice
(Oryza sativa) hulls as a pressing aid, which yielded $82.6 \%$ juice. The hulls help break berry skins and create more surface area to press the berries within the press bag. Another press without enzyme yielded $72.4 \%$ juice recovery. The forth press was heated to $50{ }^{\circ} \mathrm{C}$ for $\mathrm{l} \mathrm{h}$ with an unspecified enzyme which yielded $83.7 \%$ juice (unpublished data). This comparison helps to confirm that by applying heat and enzyme to break up the berries, whether physically or enzymatically, juice recovery is increased.

\section{Conclusion}

A relatively rapid, low-input juicing process for production of local NFC blueberry juice was determined by evaluating variations in the juice process itself. Properly freezing berries to extend the juicing period did not decrease juice recovery. This is an important result for small-scale or local commercial juicers for year round production and consumption. Heating the berries before pressing, as well as an added pectinase enzyme resulted in greatly increased juice recovery and less visible moisture content in the press cake. In the comparison of berry species, the SHB blueberries produced more juice in all treatments than RAB blueberries, presumably due to the complexity of the pectins in the RAB blueberries. On a pilot scale, results were comparable to the bench top experiment, with a $74 \%$ juice recovery. However, in an industrial scale process, one could expect up to $87 \% \pm$ $0.6 \%$ total juice recovery using pilot plant procedures outlined herein. Experiments testing variations on temperatures and pressing aids, such as the rice hulls, could be used to further optimize and increase juice recovery. Likewise, expanded evaluations of cell wall and membrane degrading enzyme combinations beyond pectinases (i.e., proteases or lipases) to improve juicing efficiency may increase anthocyanin extraction and increase the phytochemical content of the juice.

\section{Literature cited}

Barkla, C. 2011. Fruit juices, p. 1-21. Market News Service. Intl. Trade Centre, Geneva, Switzerland.

Bates, R.P., J.R. Morris, and P.G. Crandall. 2001. Principles and practices of small and medium scale fruit juice processing. FAO Agr. Serv. Bul. 146.
Boches, P., N.V. Bassil, and L. Rowland. 2006. Genetic diversity in the highbush blueberry evaluated with microsatellite markers. J. Amer. Soc. Hort. Sci. 131:674686.

Brambilla, A., R. Lo Scalzo, G. Bertolo, and D. Torreggiani. 2008. Steam-blanched highbush blueberry (Vaccinium corymbosum L.) juice: Phenolic profile and antioxidant capacity in relation to cultivar selection. J. Agr. Food Chem. 56:2643-2648.

Brownmiller, C., L.R. Howard, and R.L. Prior. 2008. Processing and storage effects on monomeric anthocyanins, percent polymeric color, and antioxidant capacity of processed blueberry products. J. Food Sci. 73:H72-H79.

Deng, J., Z.-J. Shi, X.-Z. Li, and H.-M. Liu. 2013. Soluble polysaccharides isolation and characterization from rabbiteye blueberry (Vaccinium ashei) fruits. BioResources 8:405-419.

Diaz, J.V., G.E. Anthon, and D.M. Barrett. 2007. Nonenzymatic degradation of citrus pectin and pectate during prolonged heating: Effects of $\mathrm{pH}$, temperature, and degree of methyl esterification. J. Agr. Food Chem. 55:5131-5136.

Folmer, F., U. Basavaraju, M. Jaspars, G. Hold, E. El-Omar, M. Dicato, and M. Diederich. 2014. Anti-cancer effects of bioactive berry compounds. Phytochem. Rev. 13:295-322.

Gerard, K.A. and J.S. Roberts. 2004. Microwave heating of apple mash to improve juice yield and quality. Lebensm. Wiss. Technol. 37:551-557.

Gössinger, M., S. Moritz, M. Hermes, S. Wendelin, H. Scherbichler, H. Halbwirth, K. Stich, and E. Berghofer. 2009. Effects of processing parameters on colour stability of strawberry nectar from puree. J. Food Eng. 90:171-178.

Grassin, C. and P. Fauquembergue. 1996. Fruit juices, p. 226-264. In: T. Godfrey and $S$. West (eds.). Industrial enzymology. MacMillan, London, UK.

Horváth-Kerkai, E. 2007. Manufacturing fruit beverages, p. 205-215. In: Y.H. Hui (ed.). Handbook of fruits and fruit processing. Wiley-Blackwell, Hoboken, NJ.

Howard, L.R., R.L. Prior, R. Liyanage, and J.O. Lay. 2012. Processing and storage effect on berry polyphenols: Challenges and implications for bioactive properties. J. Agr. Food Chem. 60:66786693.

Jaeger, H., M. Schulz, P. Lu, and D. Knorr. 2012. Adjustment of milling, mash electroporation and pressing for the development of a PEF assisted juice production 
in industrial scale. Innov. Food Sci. Emerg. Technol. 14:46-60.

Khurana, S., K. Venkataraman, A. Hollingsworth, M. Piche, and T. Tai. 2013. Polyphenols: Benefits to the cardiovascular system in health and in aging. Nutrients 5:37793827.

Landbo, A.-K., K. Kaack, and A.S. Meyer. 2007. Statistically designed two step response surface optimization of enzymatic prepress treatment to increase juice yield and lower turbidity of elderberry juice. Innov. Food Sci. Emerg. Technol. 8:135142 .

Lee, J., R.W. Durst, and R.E. Wrolstad. 2002. Impact of juice processing on blueberry anthocyanins and polyphenolics: Comparison of two pretreatments. J. Food Sci. 67:1660-1667.

Marshall, D.A., J.M. Spiers, and J.H. Braswell. 2006. Splitting severity among rabbiteye (Vaccinium ashei 'Reade') blueberry cultivars in Mississippi and Louisiana. Intl. J. Fruit Sci. 6:77-81.

Mieszczakowska-Frąc, M., J. Markowski, M. Zbrzeźniak, and W. Płocharski. 2012. Impact of enzyme on quality of blackcurrant and plum juices. Lebensm. Wiss. Technol. 49:251-256.

Moss, G.P. 1992. Recommendations of the nomenclature committee of the International Union of Biochemistry and Molecular Biology on the nomenclature and classification of enzymes by the reactions they catalyse. 23 Aug. 2015. <http://www. chem.qmul.ac.uk/iubmb/enzyme/>.
Patras, A., N.P. Brunton, C. O’Donnell, and B.K. Tiwari. 2010. Effect of thermal processing on anthocyanin stability in foods; mechanisms and kinetics of degradation. Trends Food Sci. Technol. 21:311.

Pedrolli, D.B., A.C. Monteiro, E. Gomes, and E.C. Carmona. 2009. Pectin and pectinases: Production, characterization and industrial application of microbial pectinolytic enzymes. Open Biotechnol. J. 3:9-18.

Perera, C.O. and B. Smith. 2013. Technology of processing of horticultural crops, p. 259-315. In: M. Kutz (ed.). Handbook of farm, dairy, and food machinery engineering. Academic Press, Cambridge, MA.

Puls, E.E., Jr. 1999. Commercial blueberry production. Louisiana State Univ. Agr. Ctr. Coop. Ext. Serv., Baton Rouge.

Reque, P.M., R.S. Steffens, A. Jablonski, S.H. Flôres, A.O. Rios, and E.V. de Jong. 2014. Cold storage of blueberry (Vaccinium spp.) fruits and juice: Anthocyanin stability and antioxidant activity. J. Food Compos. Anal. 33:111-116.

Silva, J.L., E. Marroquin, F.B. Matta, J.O. Garner, and J. Stojanovic. 2005. Physicochemical, carbohydrate and sensory characteristics of highbush and rabbiteye blueberry cultivars. J. Agr. Food Chem. 85:1815-1821.

Skrede, G., R.E. Wrolstad, and R.W. Durst. 2000. Changes in anthocyanins and polyphenolics during juice processing of highbush blueberries (Vaccinium corymbosum L.). J. Food Sci. 65:357-364.
Sun-Waterhouse, D. 2011. The development of fruit-based functional foods targeting the health and wellness market: A review. Intl. J. Food Sci. Technol. 46:899920.

Thomasset, S., N. Teller, H. Cai, D. Marko, D. Berry, W. Steward, and A. Gescher. 2009. Do anthocyanins and anthocyanidins, cancer chemopreventive pigments in the diet, merit development as potential drugs? Cancer Chemother. Pharmacol. 64:201-211.

U.S. Department of Agriculture. 2013a. U.S. blueberry industry. Cultivated blueberries: Commercial acreage, yield per acre, production, and season-average grower price in the United States, 1980-2012 (table08.xls). 4 Mar. 2015. <http://usda. mannlib.cornell.edu/usda/ers/blueberry/ table08.xls>.

U.S. Department of Agriculture. 2013b. U.S. blueberry industry. U.S. blueberry production and utilization (cultivated and wild), selected states, 1980-2012 (table02.xls). 4 Mar. 2015. <http://usda.mannlib.cornell. edu/MannUsda/viewDocumentInfo.do? documentID $=1765>$.

U.S. Department of Agriculture. 2015. Blueberry. Noncitrus fruits and nuts 2014 summary. 4 Mar. 2015. <http://usda. mannlib.cornell.edu/usda/current/ NoncFruiNu/NoncFruiNu-07-06-2016. pdf>.

Watrous, M. 2014. Juicing: A trend. 20 Sept. 2015 . <http://www. foodbusinessnews.net/articles/news home/Consumer_Trends/2014/04/ Slideshow_Juicing_a_trend.aspx? ID =\% 7 B 4022 ED 8D-6FFA-4781-8936F754871CBD0C\%7D>. 


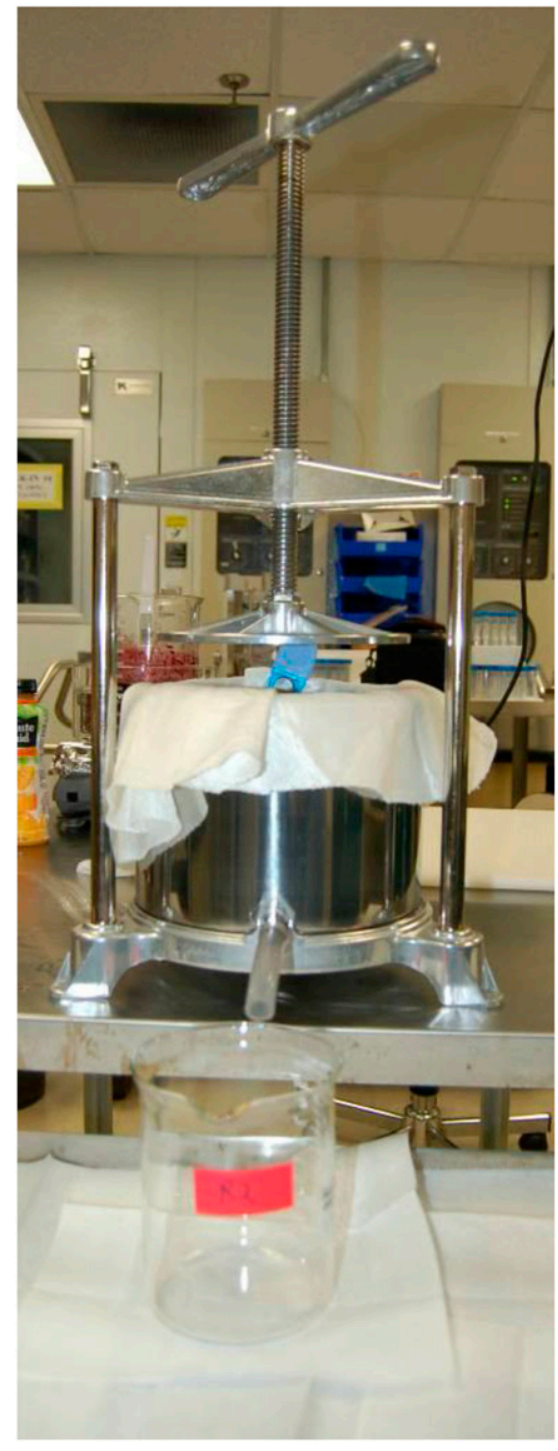

Supplemental Fig. 1. A 2.2-L (0.58 gal) stainless steel press with nylon press cloth and spigot used for bench top juice extraction of ambient and heated Mississippi-grown southern highbush blueberries and rabbiteye blueberries.

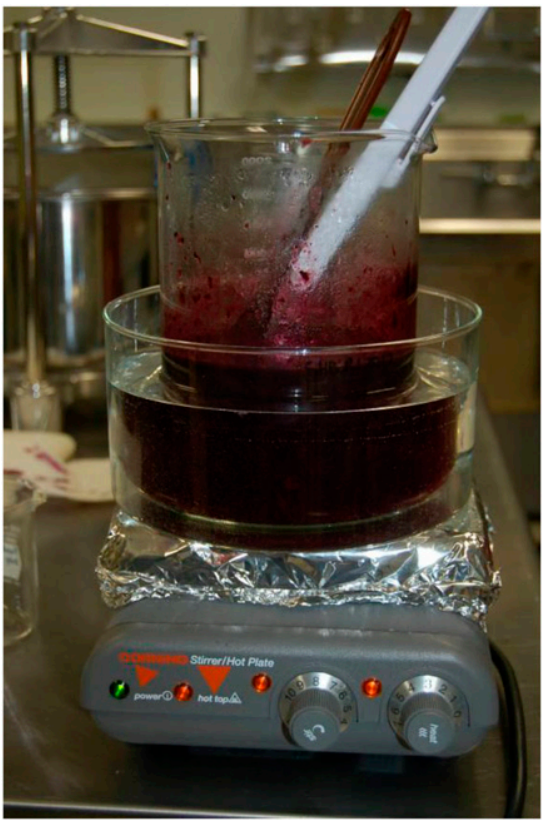

Supplemental Fig. 2. The heat treatment before pressing on a bench top hot plate to rapidly heat $1000 \mathrm{~g}$ $(2.20 \mathrm{lb})$ of rabbiteye blueberries to $95^{\circ} \mathrm{C}\left(203.0^{\circ} \mathrm{F}\right)$ while mixing.

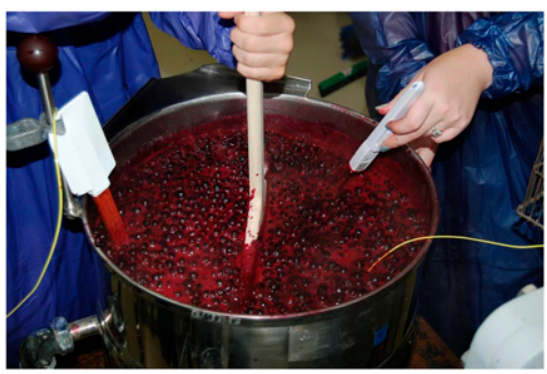

Supplemental Fig. 3. Pilot scale steam jacketed kettle heat mashing of $60 \mathrm{lb}$ $(27.2 \mathrm{~kg})$ 'Tifblue' rabbiteye blueberries to $95{ }^{\circ} \mathrm{C}\left(203.0^{\circ} \mathrm{F}\right)$ with constant stirring.

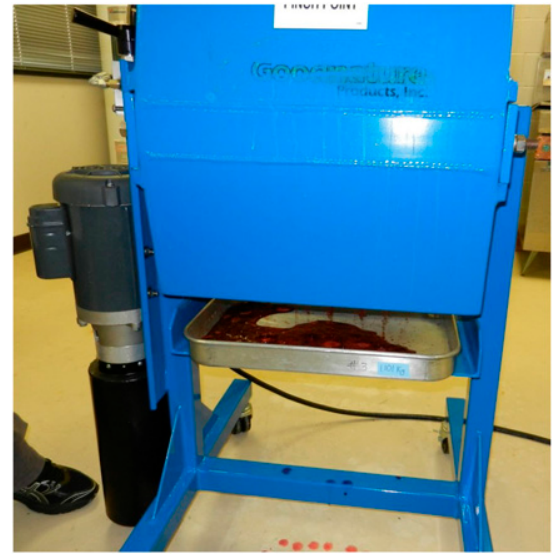

Supplemental Fig. 4. Pilot scale pressing of $60-1 \mathrm{~b}(27.2 \mathrm{~kg})$ mashed and Rohapect $10 \mathrm{~L}$ enzyme $(\mathrm{AB}$ Enzymes, Darmstadt, Germany) treated 'Tifblue' rabbiteye blueberries in an 1800-psi (12.41 MPa) hydraulic press (model X-1; Goodnature, Orchard Park, NY), showing the juice flowing out the bottom of the press into a stainless steel pan.

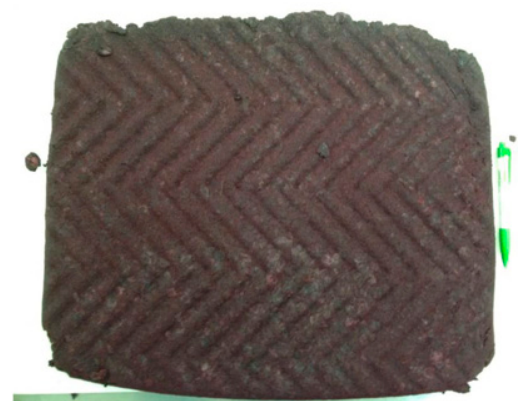

Supplemental Fig. 5. Press cake with press plate imprint resulting from $60 \mathrm{lb}(27.2 \mathrm{~kg})$ of mashed and Rohapect 10 L enzyme (AB Enzymes, Darmstadt, Germany) treated 'Tifblue' rabbiteye blueberries pressed in an 1800-psi (12.41 MPa) hydraulic press (model X-1; Goodnature, Orchard Park, NY). 


\section{Research Reports}

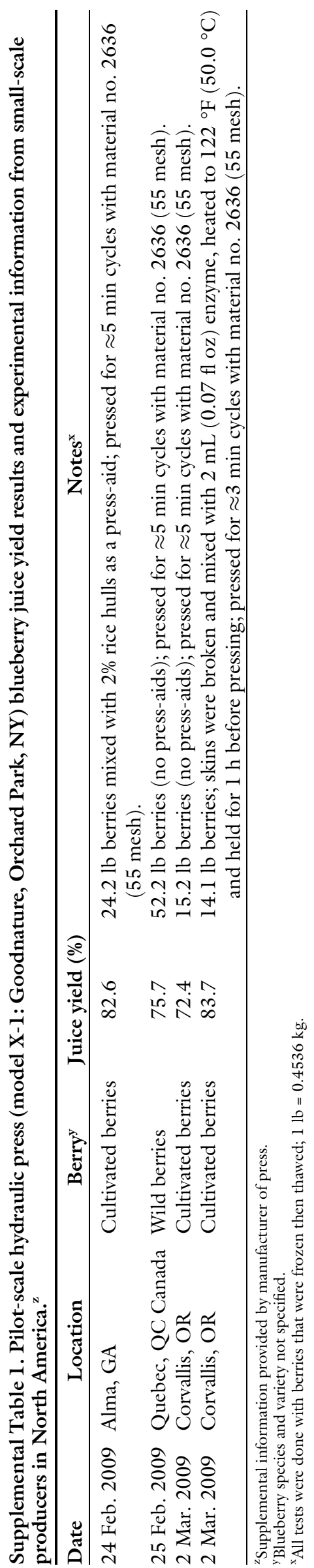

